\title{
Thermodynamics of Xenon Binding to Cryptophane in Water and Human Plasma
}

\section{Supporting Information}

\author{
P. Aru Hill, ${ }^{\dagger}$ Qian Wei, ${ }^{\dagger}$ Roderic G. Eckenhoff, ${ }^{\ddagger}$ Ivan J. Dmochowski ${ }^{*},{ }^{\dagger}$ \\ ${ }^{\dagger}$ Department of Chemistry, University of Pennsylvania Department of Anesthesia and \\ Critical Care, University of Pennsylvania
}

\section{CONTENTS:}

Reagents and General Methods

Synthesis of 2,7,12- Tris [2-[4-(hydroxymethyl)-2-propargyloxyphenoxy]ethoxy]-3,8,13trimethoxy-10,15-dihydro-2H-tribenzo[a,d,g]cyclononene (3)

Tripropargyl Cryptophane-A (5)

Calculation of Aqueous Xenon Concentration

Saturated Aqueous Xenon Solutions for Fluorescence Quenching Experiments

Xenon Quenching of Cryptophane Fluorescence

Isothermal Titration Calorimetry of Tri-acid Cryptophane $\mathbf{1}$ in Phosphate Buffer 
Figure S1. Hyperpolarized ${ }^{129} \mathrm{Xe}$ spectrum of $60 \mu \mathrm{M} 1$ in $1 \mathrm{mM} \mathrm{pH} 7.2$ phosphate buffer S5

Figure S2. Enthalpograms of $\mathbf{1}(80 \mu \mathrm{M})$ in $20 \mathrm{mM}$, pH 7.5 phosphate buffer at $293 \mathrm{~K} \quad \mathrm{~S} 7$

$\begin{array}{lr}\text { Figure S3. Buffer controls at } 293 \mathrm{~K} & \text { S8 }\end{array}$

$\begin{array}{lr}\text { Figure S4. Buffer controls at } 310 \mathrm{~K} & \text { S8 }\end{array}$

$\begin{array}{lr}\text { Figure S5. Plasma controls at 310 K } & \text { S10 }\end{array}$

Figure S6. Plotted xenon thermodynamic parameters of solvation $\left(\mathrm{Xe}_{(\mathrm{g})} \rightarrow \mathrm{Xe}_{(\mathrm{aq})}\right) \quad \mathrm{S} 11$

Table S1. Thermodynamic binding parameters of Xe @ 1 obtained by ITC S11

Reagents. Organic reagents and solvents were used as purchased from the following commercial sources:

Sigma-Aldrich: methanol, 2,6-lutidine;

Acros: cesium carbonate, anhydrous dimethylsulfoxide (DMSO), anhydrous dimethylformamide (DMF), $70 \%$ perchloric acid, $d_{6} \mathrm{DMSO}, \mathrm{CDCl}_{3}$;

Fisher: sodium chloride, potassium phosphate, ethyl acetate, dichloromethane, hydrochloric acid, sodium hydroxide, sodium sulfate, acetone, hexanes;

Cambridge Isotope Laboratories: deuterium oxide;

Airco Industrial Gases: research grade xenon gas.

General Methods. All organic reactions were carried out under nitrogen atmosphere. ${ }^{1} \mathrm{H}$ NMR $(500.14 \mathrm{MHz})$ and ${ }^{13} \mathrm{C}(125.77 \mathrm{MHz})$ spectra were obtained on a Bruker AMX 500 spectrometer at the University of Pennsylvania NMR facility. Spectra were referenced to TMS at 0.00 in $\mathrm{CDCl}_{3}$ or the residual solvent peak at 2.50 in $d_{6}$ DMSO. Electrospray ionization mass spectrometry was performed in low resolution mode on a Micromass LC Platform and in high resolution mode on a Micromass Autospec at the Mass Spectrometry Center in the Chemistry Department at the University of Pennsylvania. For fluorescence and ITC measurements in buffer, solutions were prepared with deionized (DI) water obtained from Mar Cor Premium Grade Mixed Bed Service Deionization. Column chromatography was performed using $60 \AA$ porosity, 40-75 $\mu \mathrm{m}$ particle size silica gel form Sorbent Technologies. Thin layer chromatography (TLC) was performed using silica gel plates with UV light at $254 \mathrm{~nm}$ for detection.

Cyclotriguaiacylene (2) and [3-propargyloxy-4-(2-iodoethoxy)phenyl]methanol (3) were synthesized as in reference 1 .

2,7,12- Tris [2-[4-(hydroxymethyl)-2-propargyloxyphenoxy]ethoxy]-3,8,13-trimethoxy10,15-dihydro-2H-tribenzo[a,d,g]cyclononene (4): (3) (0.4759 g, $1.17 \mathrm{mmol})$ and cesium carbonate $(2.278 \mathrm{~g}, 6.99 \mathrm{mmol})$ were added to an oven dried flask with stir bar and purged with 
nitrogen gas. Dry DMF (30 mL) was added by syringe and the mixture was allowed to stir for 30 minutes at room temperature. [3-propargyloxy-4-(2-iodoethoxy)phenyl] methanol linker 3 (1.548 g, $4.66 \mathrm{mmol})$ was then added and the reaction was placed in a $55{ }^{\circ} \mathrm{C}$ oil bath with stirring. TLC analysis (80:20 EtOAc:hexanes) showed depletion of the starting cyclotriguaiacylene after 24 hours. The reaction was poured into water $(100 \mathrm{~mL})$, neutralized with dilute $\mathrm{HCl}$, and extracted 3 times with EtOAc $(75 \mathrm{~mL})$. The combined organics were washed 5 times with saturated $\mathrm{NaCl}(100 \mathrm{~mL})$, dried over $\mathrm{Na}_{2} \mathrm{SO}_{4}$, and evaporated under reduced pressure. The crude material was then pumped under high vacuum overnight to remove any residual DMF. After adsorption onto silica gel the crude material was purified by column chromatography (80:20 EtOAc:hexanes $\rightarrow 20: 80 \mathrm{MeOH}:$ EtOAc) to yield $717 \mathrm{mg}$ (60\% yield) of 4 as a white powder. ${ }^{1} \mathrm{H}$ NMR $\left(\mathrm{CDCl}_{3}\right) \delta=7.03(\mathrm{~s}, 3 \mathrm{H}$, aryl), $6.98(\mathrm{~s}, 3 \mathrm{H}$, aryl), $6.89(\mathrm{~s}, 6 \mathrm{H}$, aryl), $6.81(\mathrm{~s}, 3 \mathrm{H}$, aryl $), 4.73\left(\mathrm{~d}, 3 \mathrm{H}, \mathrm{J}=13.6, \mathrm{H}_{\mathrm{ax}}\right), 4.59\left(\mathrm{~s}, 12 \mathrm{H}, \mathrm{Ph}-\mathrm{CH}_{2}-\mathrm{OH},-\mathrm{OCH} 2 \mathrm{C} \equiv \mathrm{CH}\right)$, 4.34 (m, 12H, -O-CH2-CH2-O), 3.70 (s, 9H, -O-CH3), 3.53 (d, 3H, d, J = 13.8 Hz, Heq $), 2.44$ (t, $3 \mathrm{H}, \mathrm{J}=2.2 \mathrm{~Hz},-\mathrm{OCH} 2 \mathrm{C} \equiv \mathrm{CH}) .{ }^{13} \mathrm{C} \mathrm{NMR}\left(\mathrm{CDCl}_{3} / \mathrm{DMSO}\right) \delta=148.53(3 \mathrm{C}), 148.25(3 \mathrm{C}), 147.39$ (3C), 146.76 (3C), 134.82 (3C), 133.22 (3C), 132.05 (3C), 121.10 (3C), 116.80 (3C), 114.96 (3C), $114.56(3 \mathrm{C}), 114.02(3 \mathrm{C}), 78.77(3 \mathrm{C},-\mathrm{OCH} 2 \mathrm{C} \equiv \mathrm{CH}), 75.73(3 \mathrm{C},-\mathrm{OCH} 2 \mathrm{C} \equiv \mathrm{CH}), 68.28$ (3C, - $\mathrm{CH} 2-\mathrm{OH}), 67.97$ (3C, -O-CH2-CH2-O), 64.18, 57.11 (3C,-O-CH2-CH2-O), 56.16, 36.32 (3C, Ar-CH2-Ar). HRMS calculated for $\mathrm{C}_{60} \mathrm{H}_{60} \mathrm{O}_{15}\left(\mathrm{M}+\mathrm{Na}^{+}\right)$1043.382992; found 1043.3751 .

\section{Tripropargyl Cryptophane-A (5): 2,7,12-Tris [2-[4-(hydroxymethyl)-2-} propargyloxyphenoxy]ethoxy]-3,8,13-trimethoxy-10,15-dihydro-2H-tribenzo[a,d,g]cyclononene (4) $(395.4 \mathrm{mg}, \quad 0.3872 \mathrm{mmol})$ was dissolved in $20 \mathrm{~mL} \mathrm{CH} \mathrm{Cl}_{2}$ and transferred to a 1-L roundbottomed flask with magnetic stirring. $400 \mathrm{~mL}$ of $\mathrm{MeOH}$ was added to the flask and the reaction was placed in an ice bath. $400 \mathrm{~mL}$ of $70 \% \mathrm{HClO}_{4}$ was added dropwise by addition funnel and the reaction was stirred at room temperature overnight. The reaction was then transferred to a separatory funnel and diluted with $400 \mathrm{~mL}$ sat. $\mathrm{NaCl}$ and $400 \mathrm{~mL}$ water. The resulting mixture was extracted 3 times with $200 \mathrm{~mL} \mathrm{CH}_{2} \mathrm{Cl}_{2}$. The organic layers were combined and washed with $200 \mathrm{~mL}$ water, $200 \mathrm{~mL}$ sat. $\mathrm{NaHCO}_{3}$, and finally $200 \mathrm{~mL}$ sat. $\mathrm{NaCl}$. The organic phase was dried over $\mathrm{Na}_{2} \mathrm{SO}_{4}$ and evaporated under reduced pressure. The crude material was adsorbed onto $3 \mathrm{~mL}$ silica gel and purified by column chromatography $\left(\mathrm{CH}_{2} \mathrm{Cl}_{2} \rightarrow\right.$ 10:90 acetone: $\left.\mathrm{CH}_{2} \mathrm{Cl}_{2}\right)$ to yield $179 \mathrm{mg}(48 \%)$ tripropargyl cryptophane (5). ${ }^{1} \mathrm{H} \mathrm{NMR}\left(\mathrm{CDCl}_{3}\right) \delta=6.90(\mathrm{~s}, 3 \mathrm{H}$, aryl), $6.79(\mathrm{~s}, 3 \mathrm{H}, \operatorname{aryl}), 6.76(\mathrm{~s}, 3 \mathrm{H}, \operatorname{aryl}), 6.69(\mathrm{~s}, 3 \mathrm{H}, \operatorname{aryl}), 4.68\left(\mathrm{q}, \mathrm{J}_{\mathrm{A}}=15.6, \mathrm{~J}_{\mathrm{B}}=2.3,-\mathrm{OCH}_{2} \mathrm{CH}_{2} \mathrm{O}-\right.$, $6 \mathrm{H}), 4.56\left(\mathrm{q}, \mathrm{J}_{\mathrm{A}}=15.6, \mathrm{~J}_{\mathrm{B}}=2.3,-\mathrm{OCH}_{2} \mathrm{CH}_{2} \mathrm{O}-, 6 \mathrm{H}\right), 4.60\left(\mathrm{~d}, \mathrm{~J}=13.6,3 \mathrm{H}, \mathrm{H}_{\mathrm{ax}}\right), 4.58(\mathrm{~d}, \mathrm{~J}=13.4$ $\left.\mathrm{Hz}, 3 \mathrm{H}, \mathrm{H}_{\mathrm{ax}}\right), 4.16\left(\mathrm{~m}, 12 \mathrm{H},-\mathrm{OCH} 2 \mathrm{C} \equiv \mathrm{CH},-\mathrm{OCH}_{2} \mathrm{CH}_{2} \mathrm{O}-\right), 3.82(\mathrm{~s}, 9 \mathrm{H},-\mathrm{OCH} 3), 3.42(\mathrm{~d}, 3 \mathrm{H}, \mathrm{J}=$ $\left.13.8 \mathrm{~Hz}, \mathrm{H}_{\mathrm{eq}}\right), 3.41\left(\mathrm{~d}, \mathrm{~J}=13.9, \mathrm{H}_{\mathrm{eq}}\right), 2.69(\mathrm{t}, \mathrm{J}=2.3,-\mathrm{OCH} 2 \mathrm{C} \equiv \mathrm{CH}) .{ }^{13} \mathrm{C} \mathrm{NMR}\left(\mathrm{CDCl}_{3}\right) \delta=$ 149.91 (3C), 148.12 (3C), 147.71 (3C), 146.81 (3C), 134.32 (6C), 133.55 (3C), 131.71 (3C), 122.09 (3C), 120.90 (3C), 117.64 (3C), 114.22 (3C), 79.15 (3C), 76.37 (3C), 69.74 (3C, $\left.\mathrm{OCH}_{2} \mathrm{CH}_{2} \mathrm{O}-\right), 69.57$ (3C, $\left.-\mathrm{OCH}_{2} \mathrm{CH}_{2} \mathrm{O}-\right), 57.62$ (3C), 56.42 (3C), 36.45 (6C Ar-CH2-Ar). HRMS calculated for $\mathrm{C}_{60} \mathrm{H}_{54} \mathrm{O}_{12}\left(\mathrm{M}+\mathrm{Na}^{+}\right)$989.355370; found 989.351298.

Tri-acid Cryptophane-A (1) : Tripropargyl cryptophane (5) (130.0 mg, 0.1344 mmol), sodium azide (43.7 mg, $0.672 \mathrm{mmol}$ ), 3-bromopropionic acid, (102.8 mg, $0.672 \mathrm{mmol}$ ), copper (II) sulfate $(2.0 \mathrm{mg}, 0.013 \mathrm{mmol}), 2,6$ lutidine $(1.4 \mathrm{mg}, 0.013 \mathrm{mmol})$, sodium ascorbate $(5.3 \mathrm{mg}$, $0.026 \mathrm{mmol}$ ), and $\mathrm{K}_{2} \mathrm{CO}_{3}(93 \mathrm{mg}, 0.67 \mathrm{mmol})$ were added to a glass vial with septum cap. Dry DMSO $(2.0 \mathrm{~mL})$ was added and the reaction was magnetically stirred under nitrogen overnight. Alternately, the reaction was monitored by TLC (10:90 HOAc:MeCN) and stopped when only 
the product spot was visible at $\mathrm{R}_{\mathrm{f}}=0.12$. If the reaction has not gone to completion in 12 hours, an additional 0.2 equivalents of sodium ascorbate may be added. After completion, the reaction was frozen and lyophilized. Purification of the resulting solid was as follows: The reaction was dissolved in $2.0 \mathrm{~mL}$ DI water and precipitated with $1.0 \mathrm{M} \mathrm{HCl}$. The mixture was then centrifuged and the supernatant discarded. The solids were resuspended in DI water, dissolved by dropwise addition of $1 \mathrm{M} \mathrm{NaOH}$, re-precipitated with $1 \mathrm{M} \mathrm{HCl}$, and centrifuged to separate the supernatant. Finally, the solids were suspended in DI water, sonicated for 10 minutes, centrifuged to remove the supernatant, and lyophilized to yield $162 \mathrm{mg}(92 \%)$ of 1 as a white powder. ${ }^{1} \mathrm{H}$ NMR $\left(d_{6}\right.$-DMSO) $\delta=8.20(\mathrm{~s}, 3 \mathrm{H}$, triazole), $7.07(\mathrm{~s}, 3 \mathrm{H}$, aryl), 6.88 (s, 3H, aryl), $6.81(\mathrm{~s}, 3 \mathrm{H}$, aryl $), 6.80(\mathrm{~s}, 3 \mathrm{H}, \operatorname{aryl}), 5.05\left(\mathrm{AB}, \mathrm{J}_{\mathrm{A}}=35.6 \mathrm{~Hz}, \mathrm{~J}_{\mathrm{B}}=12.0 \mathrm{~Hz}, 6 \mathrm{H}\right), 4.63(\mathrm{t}, 6 \mathrm{H}, \mathrm{J}=$ $6.7 \mathrm{~Hz}), 4.52\left(\mathrm{~d}, \mathrm{~J}=13.3 \mathrm{~Hz}, 3 \mathrm{H}, \mathrm{H}_{\mathrm{ax}}\right), 4.49\left(\mathrm{~d}, \mathrm{~J}=13.3 \mathrm{~Hz}, 3 \mathrm{H}, \mathrm{H}_{\mathrm{ax}}\right), 4.15(\mathrm{~m}, 12 \mathrm{H}$, $\left.\mathrm{OCH}_{2} \mathrm{CH}_{2} \mathrm{O}-\right), 3.46$ (s, 9H, -OCH3), 3.36 (d, 3H, J = 13.6, $\mathrm{H}_{\mathrm{eq}}$ ), 3.32 (d, 3H, J = 13.5 Hz, Heq), $2.94(\mathrm{t}, 6 \mathrm{H}, \mathrm{J}=6.7 \mathrm{~Hz}) .{ }^{13} \mathrm{C}$ NMR $(\mathrm{DMSO}) \delta=171.85(3 \mathrm{C},-\mathrm{CO} 2 \mathrm{H}), 148.89,147.87,146.20$, $145.78,143.41,133.86,133.58,132.73,131.78,133.86,133.58,132.73,131.78,124.28,120.70$, 119.25, 117.35, 115.24, 68.86(3C, $\left.-\mathrm{OCH}_{2} \mathrm{CH}_{2} \mathrm{O}-\right), 68.36\left(3 \mathrm{C},-\mathrm{OCH}_{2} \mathrm{CH}_{2} \mathrm{O}-\right), 62.95,56.06$, 45.51, 35.02, 34.95, 34.25. HRMS calculated for $\mathrm{C}_{69} \mathrm{H}_{69} \mathrm{~N}_{9} \mathrm{O}_{18}\left(\mathrm{M}+\mathrm{Na}^{+}\right)$1334.472293; found 1334.465827.

${ }^{129}$ Xe NMR Spectroscopy. ${ }^{129} \mathrm{Xe}$ chemical shift data for $\mathbf{1}(60 \mu \mathrm{M})$ were collected in $0.001 \mathrm{M}$ pH 7.2 phosphate buffer on a Bruker DMX 500, $11.7 \mathrm{~T}\left({ }^{129} \mathrm{Xe}=138.2 \mathrm{MHz}\right)$ spectrometer using a $10 \mathrm{~mm}$ broadband decoupling probe (probe temperature $=300 \mathrm{~K}$ ). A gas mixture consisting of $1 \%$ xenon (natural isotopic abundance: $26.4 \%{ }^{129} \mathrm{Xe}$ and $21.3 \%{ }^{131} \mathrm{Xe}$ ), $10 \%$ dinitrogen, and $89 \%$ helium was employed at a pressure of $\sim 5 \mathrm{~atm}$. The xenon was polarized in a homebuilt polarizer (output polarization $=2 \%$ ) using a Coherent Dual FAP $50 \mathrm{~W}$ diode laser system operating at $794.8 \mathrm{~nm}$ in a continuous flow system. The laser polarized xenon was frozen out in a cold finger trap with liquid nitrogen in a strong magnetic field. The polarized xenon was quickly thawed with hot water and transferred to a $10 \mathrm{~mm}$ J-Young valve NMR tube containing the sample solution.

The reference for the bound xenon chemical shift is xenon gas $(\delta=+0.55 \mathrm{ppm}$ at $300 \mathrm{~K}) .^{3}$ The tube was purposely filled to include a small volume of gaseous headspace within the detection area of the receiver coils. This allowed the observation of, and reference to, the gaseous xenon signal. 
Figure S1: Hyperpolarized ${ }^{129} \mathrm{Xe}$ spectrum of $60 \mu \mathrm{M} 1$ in $1 \mathrm{mM}$ pH 7.2 phosphate buffer.

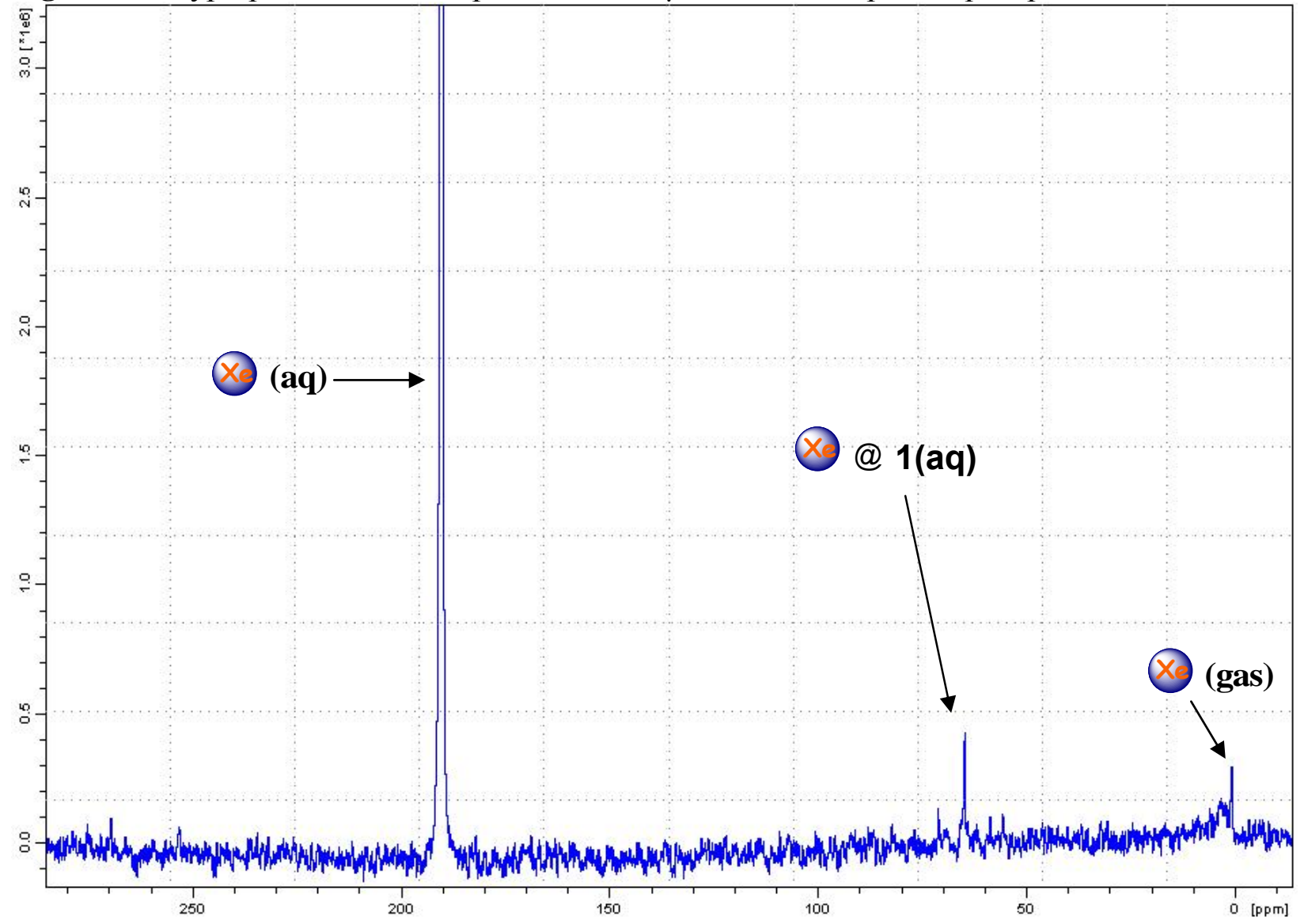

Calculation of Aqueous Xenon Concentration. The mole fraction $(\chi l)$ of xenon in water at $101.325 \mathrm{kPa}$ pressure was calculated by Rubin Battino based on the data of three workers. ${ }^{2}$ The best fit for the 20 data points is given by the following expression:

$\ln \chi=-74.7398+105.210 /(\mathrm{T} / 100 \mathrm{~K})+27.4664 \ln (\mathrm{T} / 100 \mathrm{~K})$

where $\chi$ is the mole fraction solubility at $101.325 \mathrm{kPa}$ pressure.

If $\mathrm{n}(\mathrm{g})$ and $\mathrm{n}(\mathrm{l})$ are the number, in moles, of xenon and water, the mole fraction solubility of xenon $(\chi(\mathrm{g}))$ for this binary system is given by:

$\chi(\mathrm{g})=\mathrm{n}(\mathrm{g}) /[\mathrm{n}(\mathrm{g})+\mathrm{n}(\mathrm{l})]$

The maximum value of $\chi(\mathrm{Xe})$ is 0.0018 at $273 \mathrm{~K}$.

Assuming that xenon saturation does not significantly change the volume of the water and the concentration of water is $55.525 \mathrm{~mol} / \mathrm{L}$, then for a 1-liter system the value of $55.525 \mathrm{~mol} \mathrm{H}_{2} \mathrm{O}$ 
may be substituted for $\mathrm{n}(\mathrm{l})$ in the mole fraction solubility equation, and equation 2 divided by $\mathrm{L}$ to give:

$\mathrm{n}(\mathrm{g}) / \mathrm{L}=\chi(\mathrm{g}) *[\mathrm{n}(\mathrm{g}) / \mathrm{L}+55.525 \mathrm{~mol} / \mathrm{L}]$

In addition, because $\mathrm{n}(\mathrm{g})$ is smaller than the molarity of bulk water by a factor of 30,000 at 273 $\mathrm{K}$, equation 3 simplifies to:

$\mathrm{n}(\mathrm{g}) / \mathrm{L}=\chi(\mathrm{g}) * 55.525 \mathrm{~mol} / \mathrm{L}$

Saturated Aqueous Xenon Solutions for Fluorescence Quenching Experiments. Deionized water was added to an acid-washed $25 \mathrm{~mL}$ Erlenmeyer flask. The flask was capped with a 14/20 septum and bubbled with argon for 20 minutes. The flask was then evacuated by high vacuum via a 22 gauge needle inserted through the septum into the headspace for 5 minutes. If the bubbling of the water became too violent, active pumping was momentarily switched to passive vacuum. When the vacuum degassing was complete, the needle was pushed to the bottom of the flask. Xenon was then bubbled through the flask for 5 minutes using a 26 gauge needle to vent excess pressure. After bubbling, the vent needle and purging needle were removed and the xenon solution was set aside. A Chemware Tedlar ${ }^{\mathrm{TM}}$ gas sampling bag with septum valve (6" $\mathrm{x}$ 6", Fisher Scientific) with $1 / 4$ " plastic tubing connected to a 16 gauge needle was pumped on high vacuum for 5 minutes and subsequently filled with xenon. The needle was then placed through the septum into the headspace of the Erlenmeyer flask containing the xenon solution. Care was taken to place a slight pressure on the bag during this process to prevent air from entering the bag through the needle. The flask-bag apparatus was placed in an incubator (typically at $310 \mathrm{~K}$ ) for a few hours to equilibrate to the desired aqueous xenon concentration. Multiple aliquots of xenon saturated water could then be carefully removed by syringe from this apparatus.

Xenon Quenching of Cryptophane Fluorescence. A stock solution of $1\left(5.1 \times 10^{-4} \mathrm{M}\right)$ in water was added to a reduced volume fluorescence cuvette with septum seal $(1.5 \mathrm{~mL}, 1 \mathrm{~cm}$ path length, Starna Cells). Phosphate buffer (0.001 M, pH 7.2) was added and the solution was bubbled with argon for 15 minutes using a needle through the septum seal. Saturated aqueous xenon at $310 \mathrm{~K}$ (3.32 $\times 10^{-3} \mathrm{M}$, see reference 2 ) was then added by syringe and the solution was allowed to equilibrate to $293 \mathrm{~K}$ in the fluorimeter for 15 minutes before fluorescence spectra were taken. For fluorescence quenching measurements, the cryptophane concentration was $1.5 \times 10^{-5} \mathrm{M}$ and the xenon concentration was varied between 0 and $9.8 \times 10^{-4} \mathrm{M}$.

Saturated xenon measurement was made by directly bubbling xenon into a degassed solution of cryptophane in the fluorescence cuvette at $273 \mathrm{~K}$ for 10 minutes. The solution was then allowed to equilibrate to $293 \mathrm{~K}([\mathrm{Xe}]=5.05 \mathrm{mM})$ for 15 minutes in the fluorimeter before spectra were taken.

There was a $1 \mathrm{~mL}$ volume headspace in the cuvette used for this study. The interface between the solution and the headspace was approximately $30 \mathrm{~mm}^{2}$.

Curve fitting was done with Igor Pro 4.01 (WaveMetrics, Inc., Oregon). 
Isothermal Titration Calorimetry of Tri-acid Cryptophane 1 in Phosphate Buffer. ITC experiments in phosphate buffer were performed using a MicroCal VP-ITC titration microcalorimeter (Northampton, MA) at $293 \mathrm{~K} .1$ was dissolved in phosphate buffer (20 mM, $\mathrm{pH} 7.5)$ and the concentration was determined by UV-Vis according to the extinction coefficient of 1 at $280 \mathrm{~nm}\left(\varepsilon_{280}=12,400 \mathrm{M}^{-1} \mathrm{~cm}^{-1}\right)$. The preparation of saturated aqueous xenon solution and the determination of xenon concentration at $293 \mathrm{~K}$ were performed by the same methodology as described in the fluorescence quenching experiment. The titrations were carried out at 293 and $310 \mathrm{~K}$. For the experiment at $310 \mathrm{~K}$, the xenon solution was incubated at $310 \mathrm{~K}$ with $1 \mathrm{~atm}$ xenon in headspace for two hours to reach equilibrium of desired concentration before loading. $1.8 \mathrm{~mL}$ of the tri-acid cryptophane solution in $20 \mathrm{mM}$ phosphate buffer was placed in the calorimeter cell, and the saturated xenon solution in water was loaded into the micro-syringe. The titration was performed by the sequential addition of $15 \mu \mathrm{L}$ aliquots of xenon solution (for a total of 29 injections) at 5-minute intervals. The heat of reaction per injection (micro-calories per second) was determined by integration of the peak areas using the Origin Version 5.0 software (1998). The values of the binding enthalpy $\left(\Delta \mathrm{H}^{\mathrm{o}}\right)$, the stoichiometry of binding $(\mathrm{n})$, and the dissociation constant $\left(K_{\mathrm{D}}\right)$ were obtained from data fitting of the heat evolved per mole of xenon injected versus the xenon/tri-acid cryptophane molar ratio using the same software. Three control experiments were performed: 1) saturated xenon solution titrated into $20 \mathrm{mM}$ phosphate buffer; 2) water titrated into the tri-acid cryptophane dissolved in $20 \mathrm{mM}$ phosphate buffer; and 3) water titrated into $20 \mathrm{mM}$ phosphate buffer to determine the heats of dilution. Processes \#1 and \#2 were subtracted from, and \#3 was added back to, the corresponding tri-acid cryptophane-xenon binding enthalpogram before curve fitting.

Figure S2. Enthalpograms of $1(80 \mu \mathrm{M})$ in 20 $\mathrm{mM}, \mathrm{pH} 7.5$ phosphate buffer at $293 \mathrm{~K}$ titrated with saturated aqueous xenon $(5.05 \mathrm{mM})$.

Time (min)

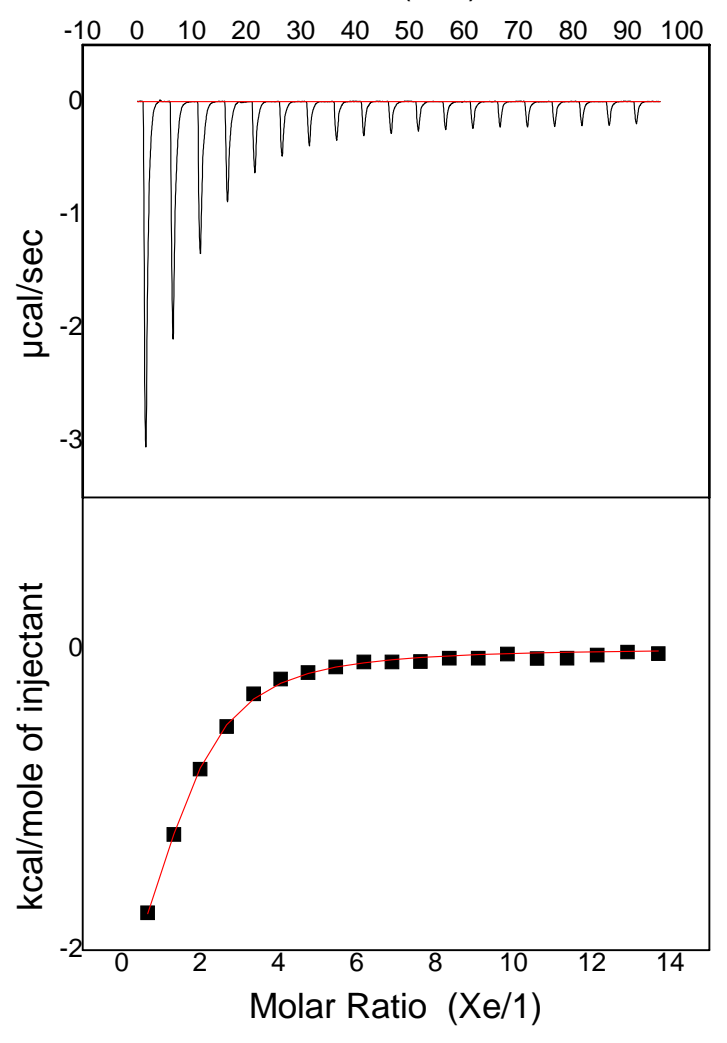


Figure S3. Buffer controls at $293 \mathrm{~K}$ : a) Water titrated into $20 \mathrm{mM}$ phosphate buffer, $\mathrm{pH} 7.5$ b) Water titrated into a solution of $\mathbf{1}$ in $20 \mathrm{mM}$ phosphate buffer, [1] $=80 \mu \mathrm{M}$ c) Xenon-saturated water titrated into $20 \mathrm{mM}$ phosphate buffer, $[\mathrm{Xe}]=5.05 \mathrm{mM}$.
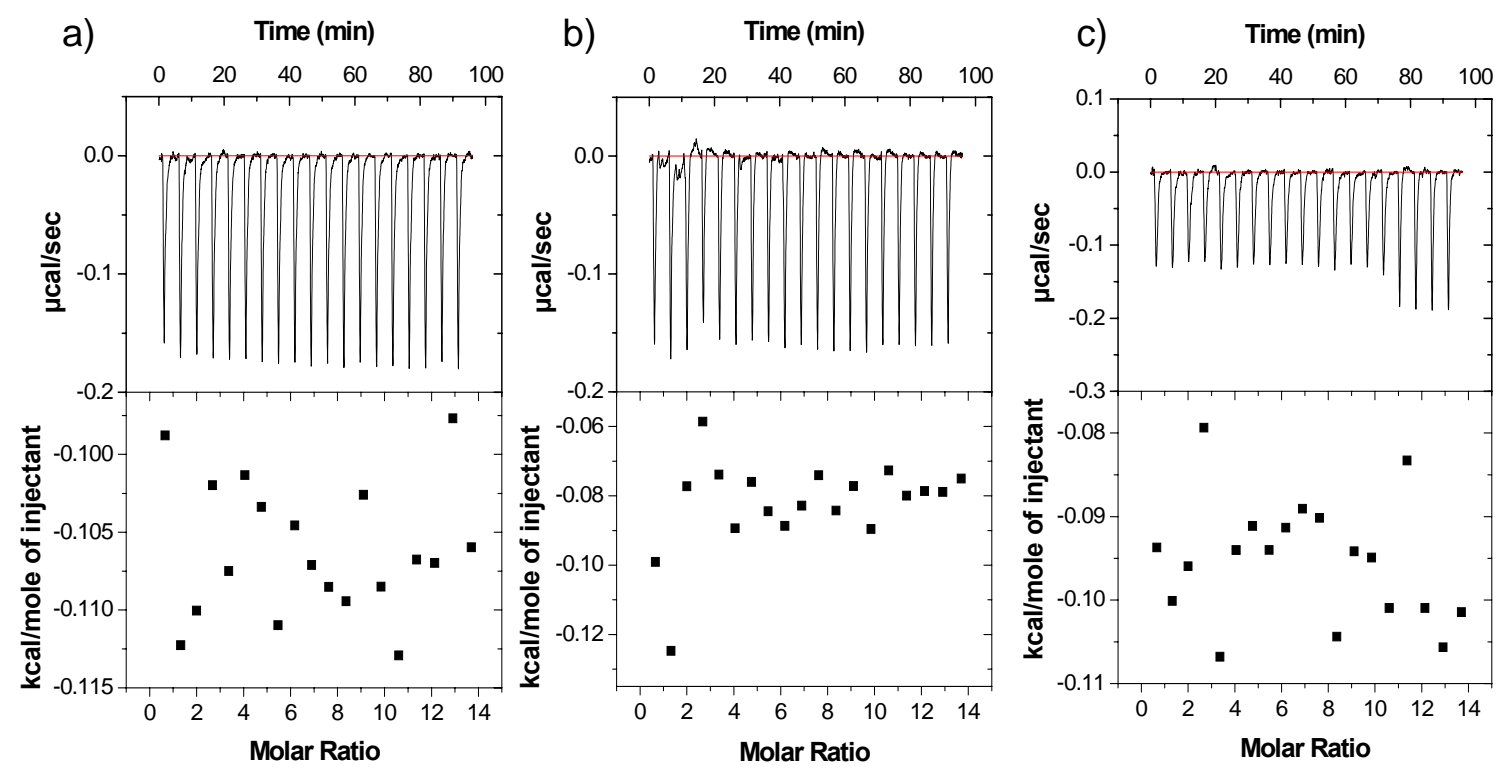

Figure S4. Buffer controls at $310 \mathrm{~K}$ : a) Water titrated into $20 \mathrm{mM}$ phosphate buffer; $\mathrm{pH} 7.5 \mathrm{~b}$ ) Water titrated into a solution of $\mathbf{1}$ in $20 \mathrm{mM}$ phosphate buffer, [1] $=88 \mu \mathrm{M}$; c) Xenon-saturated water titrated into $20 \mathrm{mM}$ phosphate buffer, $[\mathrm{Xe}]=3.3 \mathrm{mM}$.
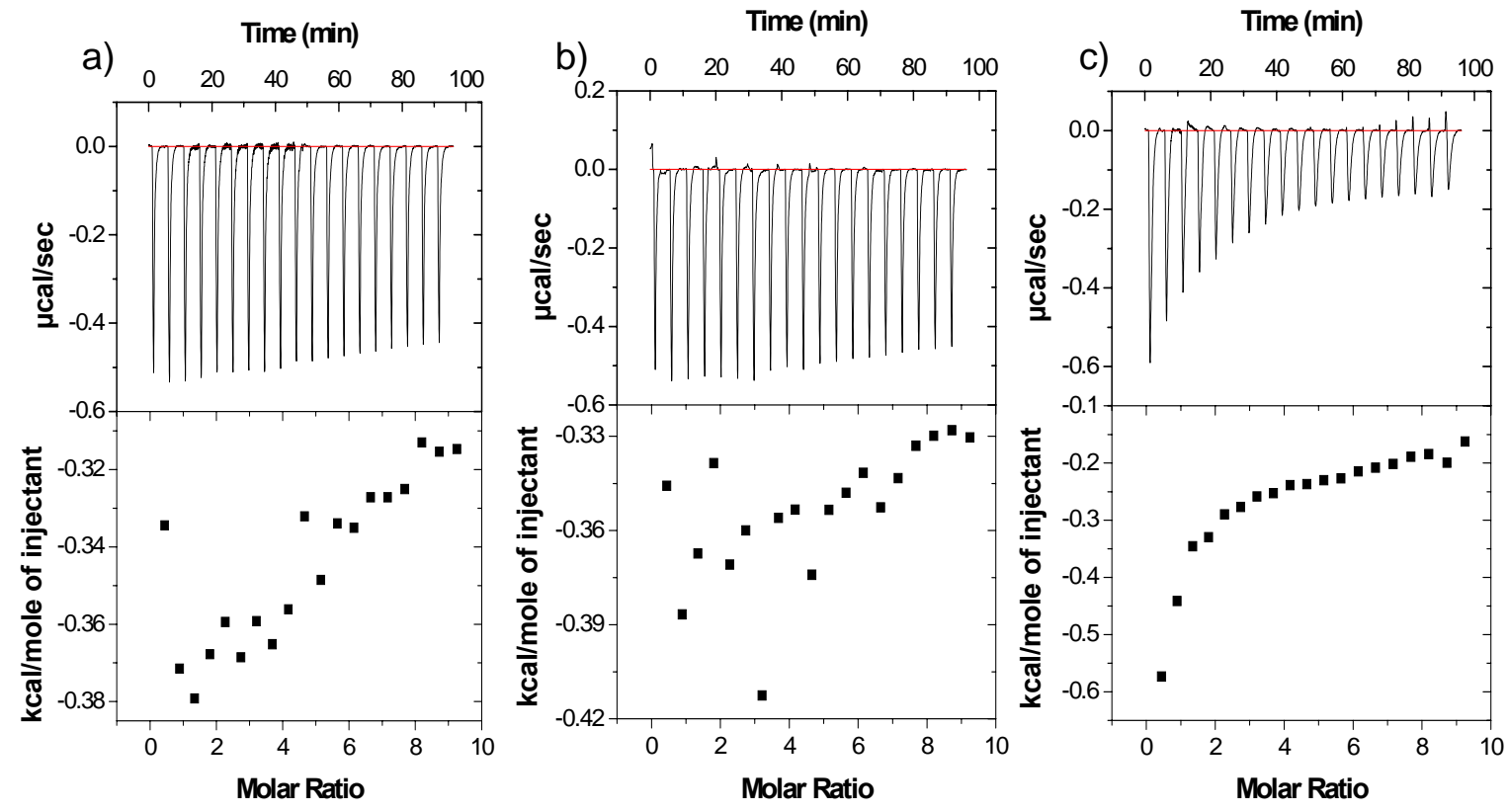
Concentration of Xenon in Saturated Human Plasma. Two independent investigations by Ladefoged, et $\mathrm{al}^{4}$ and Kitani ${ }^{5}$ calculated Ostwald Coefficients of $0.091 \pm 0.002$ and $0.094 \pm$ 0.001 , respectively, for xenon solubility in human plasma at $310 \mathrm{~K}$. This discrepancy is attributed to "slight differences in blood lipid composition and content" by Kitani. A value of $0.093 \pm 0.004$ was used in this current study to approximate the concentration of xenon in human plasma given the literature values and possible differences in plasma composition.

The Ostwald Coefficient (L) is the ratio of the volume of gas absorbed to the volume of absorbing liquid:

$\mathrm{L}=\mathrm{V}(\mathrm{g}) / \mathrm{V}(\mathrm{l})$

If Henry's Law is applicable, then the Ostwald Coefficient is independent of the partial pressure of the gas. Xenon satisfies this requirement under our experimental conditions in that its pressure varies little from ideality and its mole fraction is small in bulk water.

Therefore, 1 liter of plasma will dissolve $92.5 \pm 4 \mathrm{~mL}$ of xenon gas at 1 atm pressure at $310 \mathrm{~K}$. By the ideal gas equation this corresponds to $3.64 \pm 0.16 \mathrm{mmol} \mathrm{Xe}$, a $3.64 \pm 0.16 \mathrm{mM}$ solution.

Preparation of Xenon Saturated Human Plasma. The human plasma used in our studies (2 $\mathrm{mL}$ per ITC experiment) was obtained from Biological Specialty Corporation and stored at 273 K. For xenon saturation it was placed in a $10 \mathrm{~mL}$ Pyrex sample tube with a $14 / 20$ joint and septum. The plasma was pumped under high vacuum through a 22 gauge needle for 5 minutes at room temperature and subsequently backfilled with 30 psi xenon. The tube was then placed in C25 Incubator Shaker for mixing and incubation at $310 \mathrm{~K}$ for 30 minutes. After rotation, the tube headspace was purged with 30 psi xenon and the tube again placed in C25 Incubator Shaker. This operation was repeated for a total of three xenon atmosphere exchanges. The excess xenon pressure was released with a 26-gauge needle and the tube with 1 atm xenon in head space was placed in the Incubator Shaker for equilibration to desired xenon concentration at $310 \mathrm{~K}$ for 2 hours. At various times during incubation, the tube was vented with a 26 gauge needle to release excess pressure. This prevented foaming of the plasma when it is was later removed for ITC study.

Isothermal Titration Calorimetry of Tri-acid Cryptophane 1 in Human Plasma. A solution of $\mathbf{1}$ in plasma $(112 \mu \mathrm{M})$ was prepared by diluting a concentrated solution of $\mathbf{1}$ in phosphate buffer $(2.4 \mathrm{mM}, 94 \mu \mathrm{L})$ into $2 \mathrm{~mL}$ human plasma. The solution of $\mathbf{1}$ in plasma $(1.8 \mathrm{~mL})$ was placed in the calorimeter cell, and the saturated xenon in plasma solution was loaded into the micro-syringe. The titration was performed by the sequential addition of $15 \mu \mathrm{L}$ aliquots of xenon solution (for a total of 29 injections) at 5-minute intervals. The heat of reaction per injection (micro-calories per second) was determined by integration of the peak areas using the Origin Version 5.0 software (1998). The values of the binding enthalpy $\left(\Delta \mathrm{H}^{\circ}\right)$, the stoichiometry of binding $(\mathrm{n})$, and the dissociation constant $\left(K_{\mathrm{D}}\right)$ was obtained from data fitting of the heat evolved per mole of xenon injected versus the xenon/tri-acid cryptophane molar ratio using the same 
software. The parallel control experiments were performed, saturated xenon plasma solution titrating plasma and plasma titrating triacid cryptophane plasma solution, to determine the heats of dilution. The heats of dilution from the corresponding triacid cryptophane-xenon binding experiments were corrected as described above before curve fitting.

Figure S5. Plasma controls at $310 \mathrm{~K}$ : a) plasma titrated into plasma; b) 1 in plasma titrated into plasma, $[\mathbf{1}]=112 \mu \mathrm{M} ; \mathrm{c}$ ) xenon-saturated plasma titrated into plasma, $[\mathrm{Xe}]=4 \mathrm{mM}$.

a)

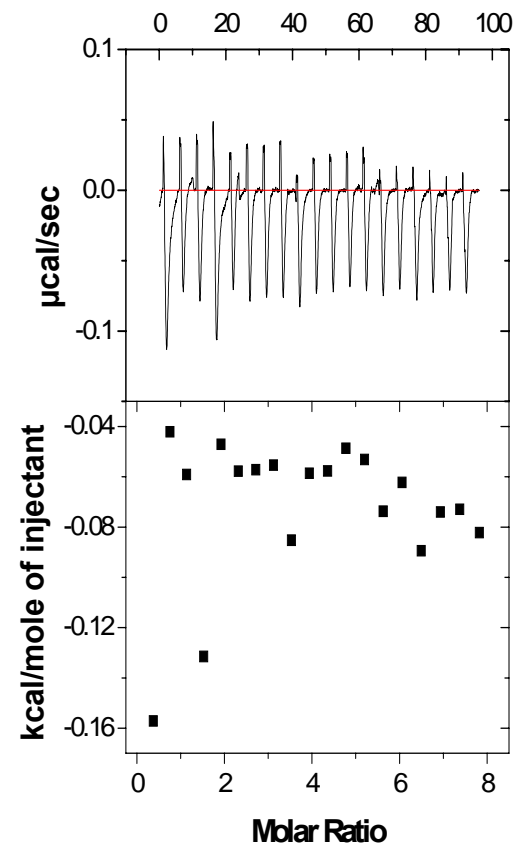

b)

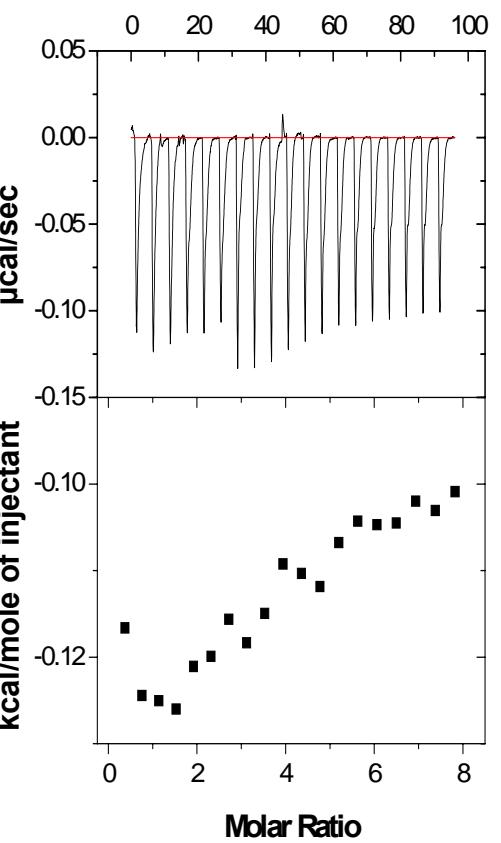

c)

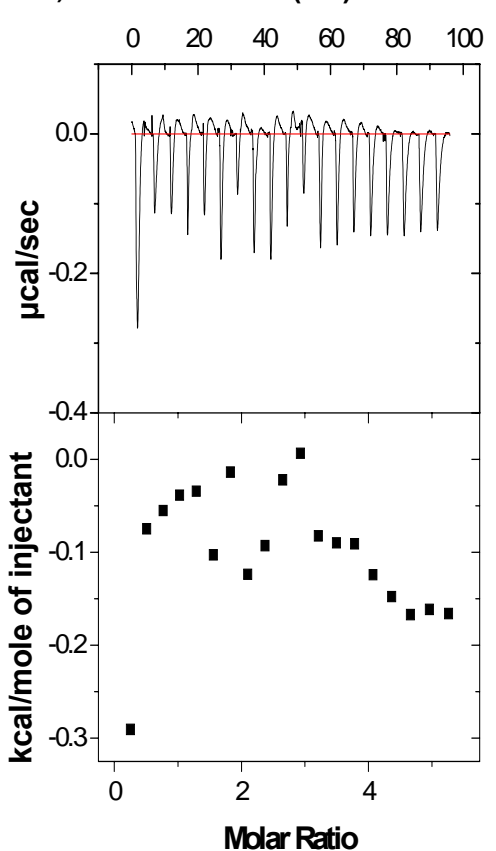

Analysis of ITC Data. The thermodynamic parameters for the transfer of xenon gas (1 atm) from the vapor phase into a hypothetical solution of unit mole fraction, as calculated by Rubin Battino in Clever's Solubility Data Series ${ }^{2}$ and converted to calories, are plotted in Figure S6. It is interesting to note the changes in the enthalpy and entropy of solvation. The enthalpy becomes less favorable with increasing temperature while the entropy actually becomes somewhat more favorable as temperature increases.

The thermodynamic parameters for xenon solvation at $310.15 \mathrm{~K}$ were linearly interpolated from the data above. The values for the temperatures in the study are as follows:

$\mathrm{Xe}_{(\mathrm{g})} \rightarrow \mathrm{Xe}_{(\mathrm{aq})}$

\begin{tabular}{lllll}
$\mathrm{T} / \mathrm{K}$ & $\Delta \mathrm{G} / \mathrm{kcal} \mathrm{mol}^{-1}$ & $\Delta \mathrm{H} / \mathrm{kcal} \mathrm{mol}^{-1}$ & $\Delta \mathrm{S} \mathrm{cal} \mathrm{K}^{-1} \mathrm{~mol}^{-1}$ & $\mathrm{~T} \Delta \mathrm{S} / \mathrm{kcal} \mathrm{mol}^{-1}$ \\
\hline 293.15 & 5.42 & -4.91 & -35.23 & -10.33 \\
310.15 & 6.00 & -3.98 & -32.16 & -9.97
\end{tabular}


Figure S6. Plotted xenon thermodynamic Parameters of Solvation $\left(\mathrm{Xe}_{(\mathrm{g})} \rightarrow \mathrm{Xe}_{(\mathrm{aq})}\right)$ from the data cited above, illustrating trends in xenon solvation energy.

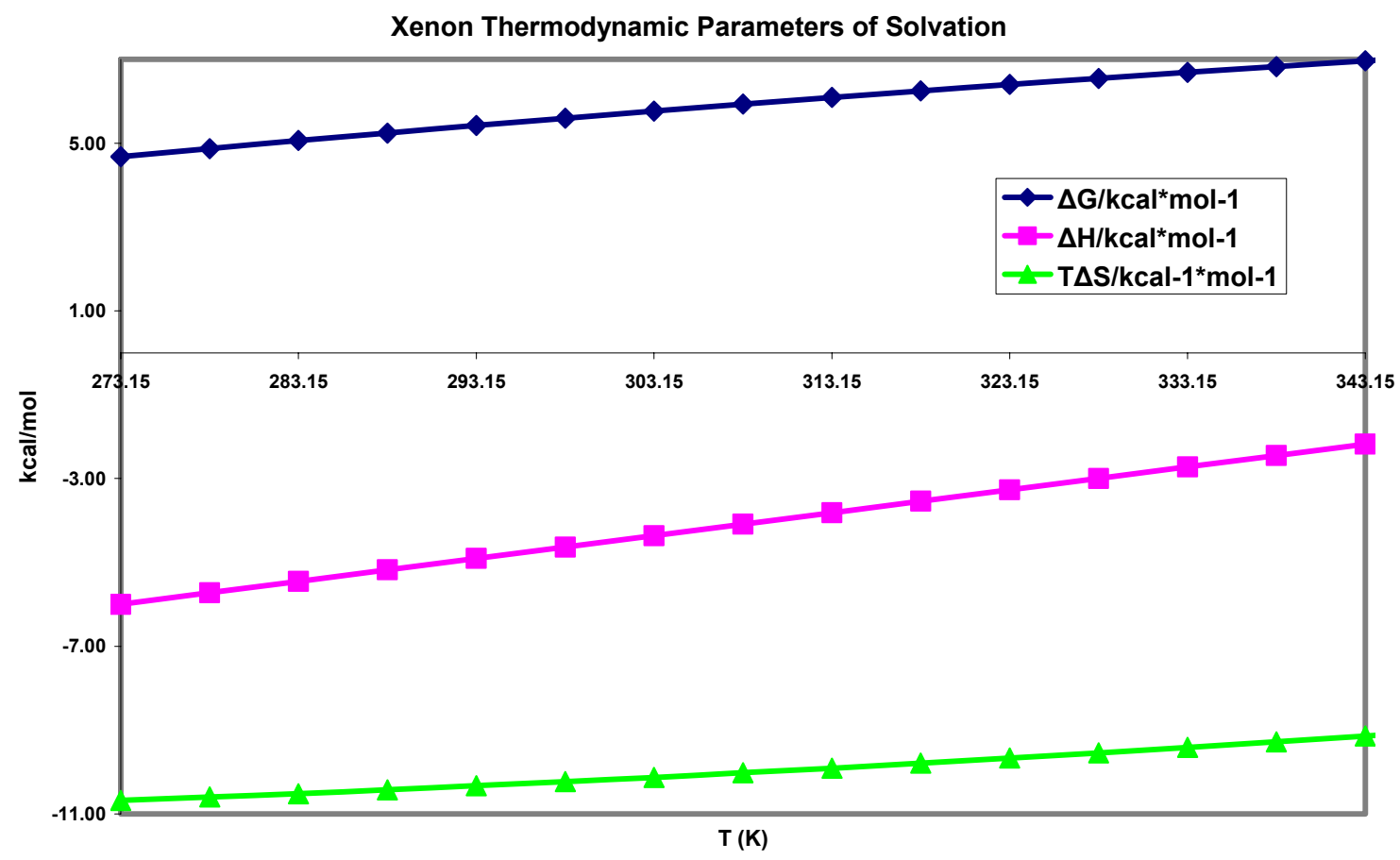

Table S1. Thermodynamic binding parameters of Xe @ 1 obtained by ITC

\begin{tabular}{|c|l|l|l|l|}
\hline & $\begin{array}{l}K_{\mathrm{A}} \\
\left(\mathrm{M}^{-1} \times 10^{4}\right)\end{array}$ & $\begin{array}{l}\Delta \mathrm{G} \\
\left(\mathrm{kcal} \mathrm{mol}^{-1}\right)\end{array}$ & $\begin{array}{l}\Delta \mathrm{H} \\
\left(\mathrm{kcal} \mathrm{mol}^{-1}\right)\end{array}$ & $\begin{array}{l}\mathrm{T} \Delta \mathrm{S} \\
\left(\mathrm{kcal} \mathrm{mol}^{-1}\right)\end{array}$ \\
\hline $\begin{array}{c}\text { Buffer } \\
293 \mathrm{~K}\end{array}$ & $1.73 \pm 0.17$ & -5.69 & $-3.14 \pm 0.20$ & 2.55 \\
\hline $\begin{array}{c}\text { Buffer } \\
310 \mathrm{~K}\end{array}$ & $3.01 \pm 0.26$ & -6.36 & $-3.56 \pm 0.13$ & 2.80 \\
\hline $\begin{array}{c}\text { Plasma } \\
310 \mathrm{~K}\end{array}$ & $2.19 \pm 0.22$ & -6.16 & $-6.04 \pm 0.33$ & 0.12 \\
\hline
\end{tabular}

At 293.15 K:

$\begin{array}{llll}\mathrm{Xe}_{(\mathrm{g})} \rightarrow \mathrm{Xe}_{(\mathrm{aq})} & \Delta \mathrm{H}=-4.91 & \Delta \mathrm{S}=-35.23 & \mathrm{~T} \Delta \mathrm{S}=-10.33 \\ \mathrm{Xe}_{(\mathrm{aq})} \rightarrow \mathrm{Xe} @ \operatorname{Crypt}_{(\mathrm{aq})} & \Delta \mathrm{H}=-3.14 \pm 0.20 & \Delta \mathrm{S}=8.7 & \mathrm{~T} \Delta \mathrm{S}=2.55\end{array}$

$\mathrm{Xe}_{(\mathrm{g})} \rightarrow \mathrm{Xe} @ \operatorname{Crypt}_{(\mathrm{aq})} \quad \Delta \mathrm{H}=-8.05 \pm 0.51 \quad \Delta \mathrm{S}=-26.53 \quad \mathrm{~T} \Delta \mathrm{S}=-7.78$

$(\Delta \mathrm{G}=-0.273 \mathrm{kcal} / \mathrm{mol})$ 
At $310.15 \mathrm{~K}$ :

$$
\begin{array}{llll}
\mathrm{Xe}_{(\mathrm{g})} \rightarrow \mathrm{Xe}_{(\mathrm{aq})} & \Delta \mathrm{H}=-3.98 & \Delta \mathrm{S}=-32.16 & \mathrm{~T} \Delta \mathrm{S}=-9.97 \\
\mathrm{Xe}_{(\mathrm{aq})} \rightarrow \mathrm{Xe} @ \operatorname{Crypt}_{(\mathrm{aq})} & \Delta \mathrm{H}=-3.56 \pm 0.13 & \Delta \mathrm{S}=9.0 & \mathrm{~T} \Delta \mathrm{S}=2.80
\end{array}
$$

$$
\begin{aligned}
& \mathrm{Xe}_{(\mathrm{g})} \rightarrow \mathrm{Xe} @ \operatorname{Crypt}_{(\mathrm{aq})} \quad \Delta \mathrm{H}=-7.54 \pm 0.28 \quad \Delta \mathrm{S}=-23.16 \quad \mathrm{~T} \Delta \mathrm{S}=-7.17 \\
& (\Delta \mathrm{G}=-0.357 \mathrm{kcal} / \mathrm{mol})
\end{aligned}
$$

The values of $\Delta \mathrm{H}\left(\mathrm{Xe}_{(\mathrm{g})} \rightarrow \mathrm{Xe} @ \mathrm{Crypt}_{(\mathrm{aq})}\right)$ in buffer at 293 and $310 \mathrm{~K}$ are both larger than the observed enthalpy of binding in plasma at $310 \mathrm{~K}$. If they are thought of as an upper limit of observable xenon binding enthalpy, then the value observed in plasma is reasonable. The thermodynamics of xenon partitioning into human plasma are not known. Plasma is a complex mixture of proteins, lipids, and salts which cannot be approximated as bulk water.

If it is assumed that the cryptophane-xenon interaction in plasma is not significantly perturbed in comparison to the interaction upon binding in buffer at $310 \mathrm{~K}\left(\Delta \mathrm{G}_{\mathrm{f}} \mathrm{Xe} @ \operatorname{Crypt}_{(\mathrm{aq})} \approx \Delta \mathrm{G}_{\mathrm{f}}\right.$ $\left.\mathrm{Xe} @ \operatorname{Crypt}_{(\text {plasma })}\right)$, it is possible to estimate the thermodynamic parameters of xenon gas partitioning into plasma:

$$
\begin{array}{lll}
\mathrm{Xe}_{(\mathrm{g})} \rightarrow \mathrm{Xe} @ \operatorname{Crypt}_{(\mathrm{aq})} \quad \Delta \mathrm{H}=-7.54 \pm 0.28 & \Delta \mathrm{S}=-23.16 & \mathrm{~T} \Delta \mathrm{S}=-7.17 \\
\mathrm{Xe} @ \text { Crypt }_{(\text {plasma) }} \rightarrow \mathrm{Xe}_{(\text {plasma) }} \Delta \mathrm{H}=6.04 \pm 0.33 & \Delta \mathrm{S}=-0.39 & \mathrm{~T} \Delta \mathrm{S}=-0.12
\end{array}
$$

$$
\begin{aligned}
& \mathrm{Xe}_{(\mathrm{g})} \rightarrow \mathrm{Xe}_{(\text {plasma })} \quad \Delta \mathrm{H}=-1.50 \pm 0.3 \quad \Delta \mathrm{S}=-23.55 \quad \mathrm{~T} \Delta \mathrm{S}=-7.30 \\
& (\Delta \mathrm{G}=5.80 \mathrm{kcal} / \mathrm{mol})
\end{aligned}
$$

This value for the Gibb's energy corresponds to a concentration of $4.5 \mathrm{mmol}$ xenon in plasma (where $\Delta \mathrm{G}=-\mathrm{R}^{*} \mathrm{~T}^{*} \ln \chi$ ) at $310 \mathrm{~K}$. This is in fair agreement with the above calculated solubility of $3.64 \pm 0.16 \mathrm{mM}$ in human plasma that came from the data of Ladefoged $^{4}$ and Kitani. ${ }^{5}$

\section{References:}

1) Wei, Q.; Seward, G. K.; Hill, P. A.; Patton, B.; Dmitrov, I. E.; Kuzma, N. N.; Dmochowski, I. J., Designing Xe-129 NMR Biosensors for Matrix Metalloproteinase Detection. J. Am. Chem. Soc. 2006, 128, 13274-13283.

2) Clever, H. L., Solubility Data Series. Pergamon Press: New York, 1979; Vol. 2, pp 1-357.

3) Jameson, C. J.; Jameson, A. K.; Cohen, S. M., Temperature and density dependence of ${ }^{129}$ Xe chemical shift in xenon gas $J$. Chem. Phys. 1973, 59, 4540-4546. 
4) Ladefoged, J.; Andersen, A. M., Solubility of Xenon- 133 at $37^{\circ} \mathrm{C}$ in Water, Saline, Olive Oil, Liquid Paraffin, Solutions of Albumin, and Blood. Phys. Med. Biol. 1967, 12, 353-358.

5) Kitani, K., Solubility Coefficients of ${ }^{85}$ Krypton and ${ }^{133}$ Xenon in Water, Saline, Lipids, and Blood. Scandinavian Journal of Clinical and Laboratory Investigations 1972, 29, 167-172. 